\title{
Temporal variation in phytoplankton community in a freshwater coastal lake of southern Brazil
}

\author{
Variação temporal na comunidade fitoplanctônica de uma \\ lagoa costeira de água doce no sul do Brasil
}

\section{Denise Tonetta $^{1}$, Mauricio Mello Petrucio $^{1}$ and Roselane Laudares-Silva ${ }^{2}$}

${ }^{1}$ Laboratório de Ecologia de Águas Continentais, Programa de Pós-graduação em Ecologia, Departamento de Ecologia e Zoologia, Centro de Ciências Biológicas, Universidade Federal de Santa Catarina - UFSC,

Campus Universitário, s/n, Trindade, CEP 88040-900, Florianópolis, SC, Brazil

e-mail: denisetonetta@yahoo.com.br; petrucio@ccb.ufsc.br

${ }^{2}$ Laboratório de Ficologia, Programa de Pós-graduação em Biologia de Fungos, Algas e Plantas,

Departamento de Botânica, Universidade Federal de Santa Catarina - UFSC,

CEP 88040-900, Florianópolis, SC, Brazil

e-mail: roselaudares@gmail.com

\begin{abstract}
Aim: The aim of the present study was to study the vertical variation in phytoplankton community in a subtropical coastal lake and to verify the temporal variation of this community following variation in temperature and dissolved nitrogen and phosphorus. Methods: Sampling of phytoplankton and abiotic variables were performed monthly from June/2009 to January/2011 at four depths from the central part of Peri Lake. The data were analyzed using analysis of variance, correlation and canonical correspondence analysis. Results: Vertical variation in the phytoplankton community and limnological data did not occur but temporal variation was found. The lake was limited by light and nutrients and this light limitation selected the Cyanobacteria species from $\mathrm{Sn}$ and S1 functional groups. Phytoplankton community was composed of five groups, with 31 freshwater taxa, in which Cyanobacteria was the most important with $87.7 \%$ of total density and Chlorophyta with $11.8 \%$. Cylindrospermopsis raciborskii was dominant during almost the whole study period because when temperature and phosphorus increased and wind speed decreased Limnothrix sp. density was boosted. Different species of Cyanobacteria filamentous showed correlation with variables in different ways, indicating that some species can co-exist, each of them having distinct niches or can compete by the same resource. Conclusion: The phytoplankton presented periodicity driven by annual change in water temperature and nutrients availability. Peri Lake's features allow for the occurrence of a vertically homogeneous water column and the dominance of cyanobacterial functional groups adapted to low underwater light and nutrients deficiency.
\end{abstract}

Keywords: subtropical lake, Cyanobacteria, Cylindrospermopsis raciborskii, nutrients, temporal variation.

Resumo: Objetivo: Nosso objetivo foi estudar a variação vertical da comunidade fitoplanctônica em uma lagoa costeira subtropical e como se comporta frente às variaçôes temporais de nutrientes e temperatura. Métodos: Para isso, amostras mensais de fitoplâncton total foram coletadas em quatro profundidades distintas de um ponto central da lagoa do Peri durante o período de junho/09 a janeiro/11, juntamente com as variáveis abióticas. Análises univariadas de variância, correlação e multivariada de correspondência canônica foram usadas para explorar os dados. Resultados: Os dados obtidos da comunidade fitoplanctônica e as demais variáveis limnológicas mostraram ausência de variação vertical na coluna d'água, no entanto ocorreu variação temporal nesse ambiente subtropical. A lagoa do Peri foi limitada por luz e por nutrientes, selecionando a ocorrência de espécies de Cyanobacteria pertencentes aos grupos funcionais Sn e S1. A comunidade fitoplanctônica foi composta por cinco grupos, com 31 taxa de água doce, sendo que Cyanobacteria, com $87,7 \%$ da densidade total foi o grupo mais importante e Chlorophyta com $11,8 \%$ foi o segundo grupo mais representativo. Cylindrospermopsis raciborskit foi a espécie dominante durante quase todo o período estudado, sendo substituída por Limnothrix sp. quando ocorreu diminuição na velocidade do vento e aumento na temperatura e na concentração de fósforo. As várias espécies filamentosas de Cyanobacteria registradas neste ambiente mostraram diferentes correlaçóes com as variáveis amostradas, sugerindo que algumas espécies podem co-existir, e outras competir pelo mesmo recurso. Conclusáo: As principais variáveis responsáveis pela variação temporal observada na comunidade fitoplanctônica foram nitrogênio, fósforo e temperatura. Cyanobacteria foi o principal constituinte do fitoplâncton, sendo representado por grupos funcionais adaptados à baixa disponibilidade de luz e baixa concentraçấo de nutrientes.

Palavras-chave: lago subtropical, Cyanobacteria, Cylindrospermopsis raciborskii, nutrientes, variação temporal. 


\section{Introduction}

The phytoplankton demonstrates spatial and temporal distribution directly influenced by light and nutrients. Changes in the concentration of nutrients, especially phosphorus, influence the conditions for phytoplankton growth and select the species growth. Previous studies indicate that excessive nutrients loading and warmer conditions promote dominance by Cyanobacteria (Zhu et al., 2010; Rejmánková et al., 2011; Kosten et al., 2012). However, Cyanobacteria dominance may be most closely related to physical and biological constraints accompanying a simple increase in nutrients supply (Downing et al., 2001; Salmaso, 2011).

The vertical distribution of species depends on the synergistic effects of climatic and hydrological variables, such as light availability and resource availability. As pointed out by Reynolds et al. (2002) and Padisák et al. (2009), phytoplankton species with resembling survival strategy form associations that potentially, and alternately, may dominate or co-dominate in a given environment.

Cylindrospermopsis raciborskii (Woloszynska) Seenayya and Subba-Raju is a filamentous Cyanobacteria, with invasive and adaptive potential, found in different regions of the world, especially in Brazilian lakes of different trophic status (Huszar et al., 2000; Crosseti and Bicudo, 2008; Dantas et al., 2012). Its ecological success is attributed to many factors like buoyancy regulation, tolerance of low light, high affinity for phosphorus and ammonia, $\mathrm{N}_{2}$ fixation ability and resistance to grazing by zooplankton (Padisák, 1997). Since 1994, in Peri Lake, a subtropical coastal lake, in which low nutrients concentration and horizontal homogeneity of chlorophyll $a$ and nutrients have been observed (Hennemann and Petrucio, 2011), filamentous cyanobacteria associations, dominated by $C$. raciborskii have been recorded (Komárková et al., 1999).

The establishment and increasing dominance of $C$. raciborskii and decreased in number of taxa found monthly in Grellmann (2006), comparing to Laudares-Silva (1999) indicates that phytoplankton composition is changing. A microcosm bioassay performed by Hennemann and Petrucio (2010) have showed that the combined effect of increased temperature and phosphorus enrichments resulted in the highest chlorophyll $a$ levels.

Thus, we hypothesized that the phytoplankton community is vertically homogeneous and that the temporal variation in nutrients and water temperature promotes changes in phytoplankton community.

\section{Material and Methods}

\subsection{Study area}

The Peri Lake ( $27^{\circ} 44^{\prime} \mathrm{S}$ and $\left.48^{\circ} 31^{\prime} \mathrm{W}\right)$ is located in the southeastern region of the Santa Catarina Island, Brazil, within Peri Lake Municipal Park that is protected by legislation. The climate in the area is characteristically subtropical, with rainfall well distributed along the year. The lake has a surface area of $5.7 \mathrm{~km}^{2}$ and average and maximum depths of $4.2 \mathrm{~m}$ and $11.0 \mathrm{~m}$ respectively. Peri Lake has two main tributaries (Cachoeira Grande and Ribeirão Grande Streams) and is a freshwater coastal lake without marine influences (freshwater year-round), making it the main freshwater resource for the island of Florianópolis (Figure 1).

\subsection{Sampling}

The environment was sampled monthly from June/2009 to January/2011. Abiotic and biotic variables were taken from the central part of lake $\left(27^{\circ} 43^{\prime} \mathrm{S}\right.$ and $\left.48^{\circ} 31^{\prime} \mathrm{W}\right)$, within different water column strata, of which the maximum depth was about $8.4 \mathrm{~m}$. Water samples were collected with a Van Dorn sampler at four depths according to the light penetration, calculated by Secchi disk (Cole, 1994): depth 1: 100\% light incident (surface), depth 2: $10 \%$ light incident $(-1.0 \mathrm{~m}$, depth Secchi disk disappears), depth 3: $1 \%$ light incident ( $-3.0 \mathrm{~m}$, Secchi disk depth multiplied by three) and depth 4: aphotic zone $(-6.0 \mathrm{~m})$. The ratio of the euphotic zone (Zeu) to mixture zone ( $\mathrm{Zmix}$ ) was used as an index of light availability in the lake.

\subsection{Abiotic variables}

The climatological variables measured in situ were wind speed with portable anemometer (Instrutherm TAD 500) and air temperature with a mercury thermometer. The precipitation accumulated for seven days prior to the day sampled was estimated from data obtained from EPAGRI/ CIRAM (Information Center for Environmental Resources and Hydrometeorology of Santa Catarina).

The following limnological variables were measured in situ, at four depths: water temperature, conductivity, $\mathrm{pH}$ and dissolved oxygen with a multiparameter probe (YSI-85). Immediately after collection, unfiltered water samples were frozen at $-20{ }^{\circ} \mathrm{C}$ to total nitrogen and phosphorus 


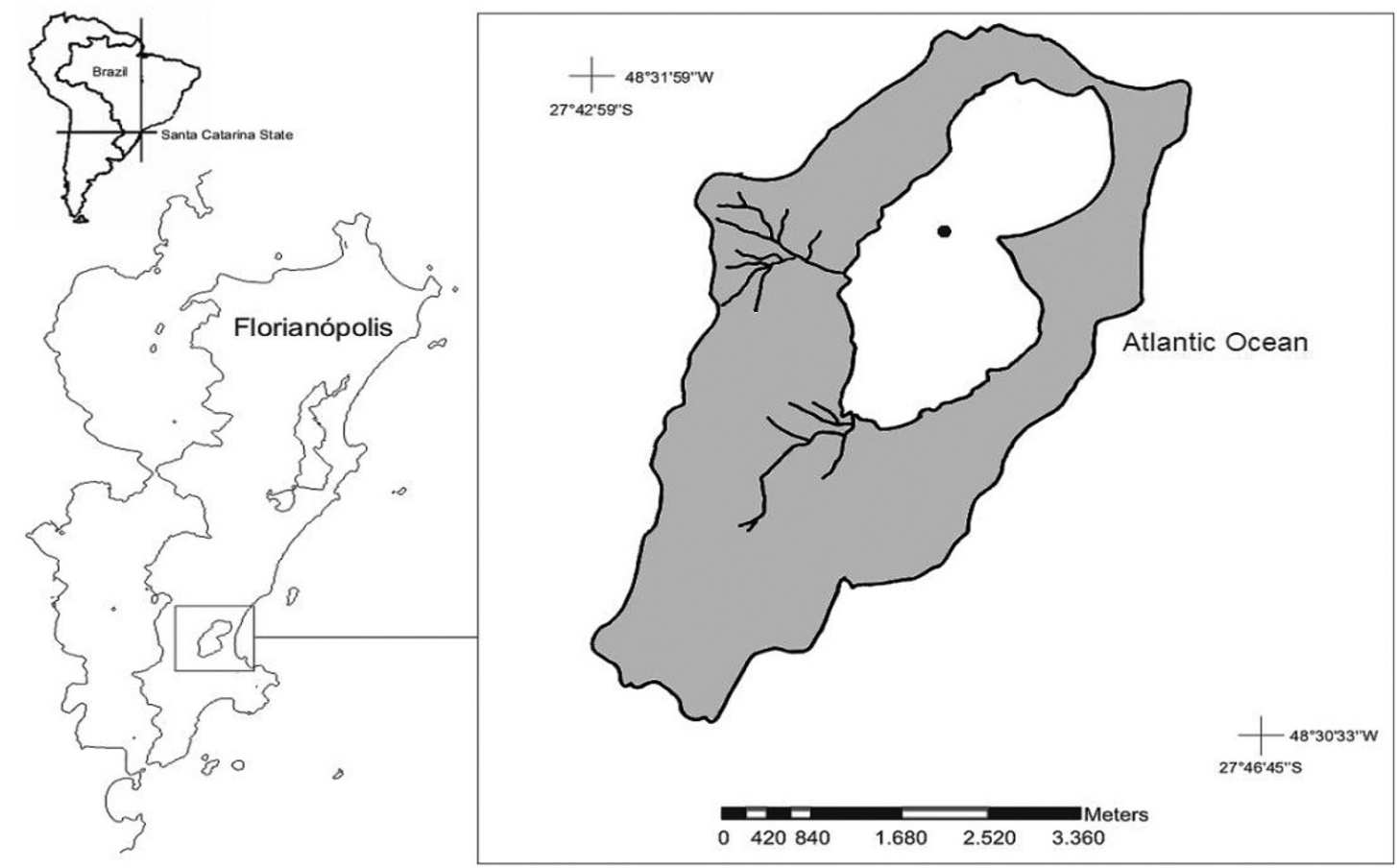

Figure 1. Map and location of the Peri Lake, Santa Catarina Island, Brazil, showing the sampled station. Adapted from Hennemann and Petrucio (2011).

determinations (Valderrama, 1981). Filtered samples were frozen to nitrite (Golterman et al., 1978), nitrate (Mackereth et al., 1978), ammonia (Koroleff, 1976) and soluble reactive phosphorus determinations (Strickland and Parsons, 1960). Filtered water samples were preserved with phosphoric acid to dissolved organic carbon determinations (Shimadzu TOC-5000A).

\subsection{Phytoplankton analyses}

The biomass of the phytoplankton community was estimated by chlorophyll a determinations, corrected for phaeophytin. Water samples were filtrated $(0.7 \mu \mathrm{m}$, Millipore AP40 glass fibre) and $90 \%$ acetone was used to pigments extraction from filters (Lorenzen, 1967).

Total phytoplankton samples from the four depths were preserved with formalin (final concentration $1.6 \%$ ), that preserve the aerotopes and make more easy the differentiation among filamentous Cyanobacteria in this environment. Aliquots were sediment with acetic Lugol's solution and investigated in inverted microscope according to Utermöhl method in Hasle (1978), in which 400 organisms (unicell, filament or colony) of the dominant species were counted. Dominant $(>50 \%$ of total density) and abundant species ( $>$ mean density) were determined (Lobo and Leighton, 1986) and occurrence of heterocyted trichomes of $C$. raciborskii was estimated only at the surface, while all individuals were identified and enumerated at four depths.

\subsection{Statistical analyses}

A nonparametric analysis of variance (KruskalWallis; $\mathrm{p}<0.05$ ) was used to test differences in the limnological variables and in phytoplankton densities between the sampling depths. Spearman correlation coefficients were used to identify significant correlations between phytoplankton and limnological variables. These analyses were completed using the software Statistica $7\left(\right.$ StatSoft $\left.^{\circledR}\right)$. The relationship between limnological variables and phytoplankton community was explored by means of a Canonical Correspondence Analysis (CCA) triplot distribution. The species density to be used in this analysis were selected through the frequency of occurrence $(>50 \%)$, since this species were considerate more representative of this environment and significance levels of limnological variables were tested with Monte Carlo (999 permutations). This analysis was completed using the program $\mathrm{R}$ version 2.13.1 (Oksanen et al., 2008; R Development Core Team, 2008). 


\section{Results}

\subsection{Abiotic variables}

Over the 20 sampling months, climatological variables showed oscillations in air temperature, measured in situ $\left(17.5^{\circ} \mathrm{C}\right.$ in June/09 to $27{ }^{\circ} \mathrm{C}$ in October and November/09) and accumulated precipitation, for the seven days previous to the sampling, reaching $61.6 \mathrm{~mm}$ day $^{-1}$ in December/10 (Figure 2). The Figure 2 shows that rainfall is well distributed along the year.

The wind speed during the sampling reached values of $9.7 \mathrm{~m} \mathrm{~s}^{-1}$ in January/10 and in some months was absent. The ratio $Z$ eu: $Z$ mix varied from 0.24 in August/09 to 0.42 in January/11 (Figure 3), indicating a low light availability. The mixture zone was considered at $11 \mathrm{~m}$ (maximum depth recorded in Peri Lake) due to be close to the sampling station.

The water temperature in surface varied from $17.6{ }^{\circ} \mathrm{C}$ in June/09 to $28.7^{\circ} \mathrm{C}$ in February/10, revealing the temporal variation during the period sampled. The $\mathrm{pH}$ was near neutrality, conductivity values were low and dissolved oxygen concentrations showed that the environment is well oxygenated. The sum mean of nitrite, nitrate and ammonia $\left(\mathrm{DIN}=25.7 \mu \mathrm{g} \mathrm{L}^{-1}\right)$ and soluble reactive phosphorus concentrations $\left(2.3 \mu \mathrm{g} \mathrm{L}^{-1}\right)$ were low, and dissolved organic carbon concentrations were relatively high, reaching $4.5 \mathrm{mg} \mathrm{L}^{-1}$ (Table 1 ).

The limnological variables at four depths did not demonstrate significant vertical variation (KruskalWallis; $\mathrm{p}>0.05$ to all variables in Table 1 ). However, when the data were grouped by months, there was significant temporal variation (Kruskal-Wallis; $\mathrm{p}<0.05)$. The minimum and maximum values of the variables in Table 1 , shows the variation over the sampling months, especially in regards to

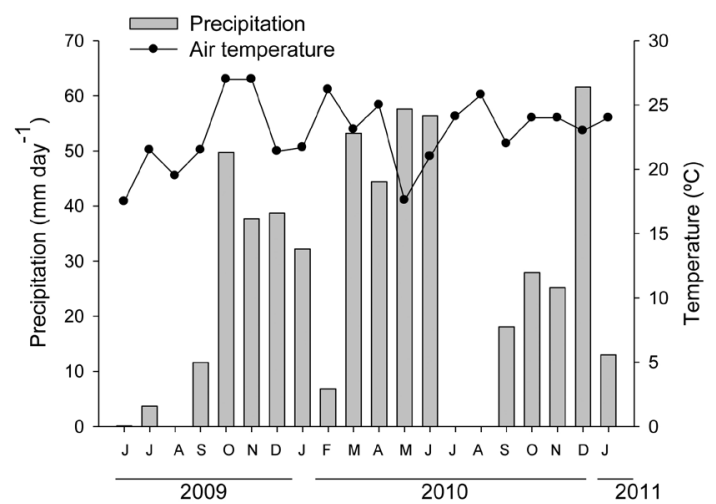

Figure 2. Precipitation accumulated in the seven days prior and air temperature during sampling in the Peri Lake, from June/2009 to January/2011. nutrients concentration, which varied strongly. The monthly variations (mean of four sampled depths) of water temperature, soluble reactive phosphorus and dissolved inorganic nitrogen forms are shown in Figure 4.

\subsection{Phytoplankton community}

The phytoplankton community was composed of five groups, with 31 freshwater taxa (20 species and 11 genus): Chlorophyta (17 taxa), Cyanobacteria (8 taxa), Bacillariophyta (3 taxa), Euglenophyta (2 taxa) and Dinophyta (1 taxa). Taxa and frequency of occurrence identified in counting chambers during all months and depths are shown in Table 2. The Figure 5 shows the total and groups phytoplankton density, in which no significant difference was evident among different depths (Kruskal-Wallis; $\mathrm{p}>0.05)$. For depth 1 the phytoplankton total density average was $118 \times 10^{3}$ ind. $\mathrm{mL}^{-1}$, for depth 2 it was $120 \times 10^{3}$ ind. $\mathrm{mL}^{-1}$, for depth 3 it was $126 \times 10^{3}$ ind. $\mathrm{mL}^{-1}$ and for depth 4 it was $119 \times 10^{3}$ ind. $\mathrm{mL}^{-1}$. On the other hand, significant temporal variation was recorded, in which total phytoplankton density varied from $34 \times 10^{3}$ ind. $\mathrm{mL}^{-1}$ in July/10 to $273 \times 10^{3}$ ind. $\mathrm{mL}^{-1}$ in September/09 (Kruskal-Wallis; $\mathrm{p}<0.05$ ). No significant vertical difference was recorded to composition and density of phytoplanktonic specific groups (Kruskal-Wallis; $\mathrm{p}>0.05$ ).

Cyanobacteria were the most important group with $87.7 \%$ of total average density followed by Chlorophyta with $11.8 \%$ (Figure 5). Dinophyta, Bacillariophyta and Euglenophyta, together, had $0.7 \%$ of total average density. Cyanobacteria was dominant during the entire study period, whose density ranged from $30 \times 10^{3}$ ind. $\mathrm{mL}^{-1}$ in July/10 to $227 \times 10^{3}$ ind. $\mathrm{mL}^{-1}$ in September/09.

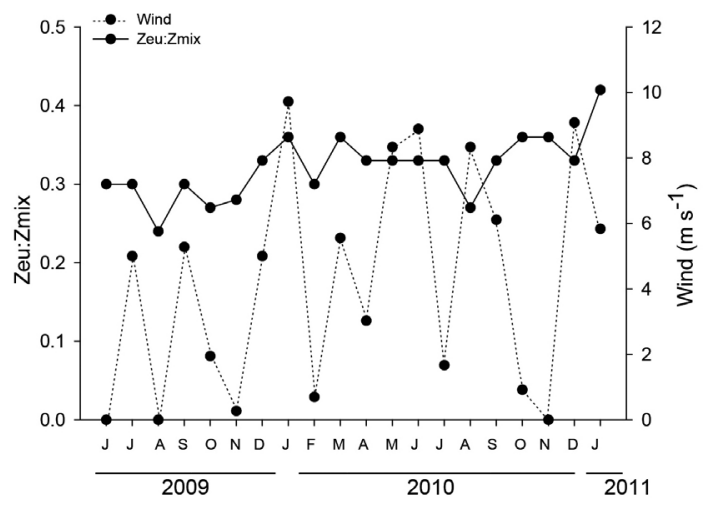

Figure 3. Ratio euphotic:mixture zone and wind speed measured during sampling in the Peri Lake, from June/2009 to January/2011. 
Table 1. Limnological variables sampled at four depths from June/09 to January/11 in the pelagic region of Peri Lake (mean, standard deviation, minimum and maximum).

\begin{tabular}{|c|c|c|c|c|}
\hline Variables & $\begin{array}{c}\text { Depth } 1 \\
\text { Mean } \pm S D \\
(\text { min-max) }\end{array}$ & $\begin{array}{c}\text { Depth } 2 \\
\text { Mean } \pm \text { SD } \\
(\text { min-max) }\end{array}$ & $\begin{array}{c}\text { Depth } 3 \\
\text { Mean } \pm \text { SD } \\
\text { (min-max) }\end{array}$ & $\begin{array}{c}\text { Depth } 4 \\
\text { Mean } \pm S D \\
\text { (min-max) }\end{array}$ \\
\hline \multirow[t]{2}{*}{ Water Temperature $\left({ }^{\circ} \mathrm{C}\right)$} & $22.4 \pm 3.69$ & $22.2 \pm 3.52$ & $22.1 \pm 3.52$ & $22.1 \pm 3.51$ \\
\hline & $(17.6-28.7)$ & $(17.5-28.7)$ & $(17.4-28.8)$ & $(17.5-28.7)$ \\
\hline \multirow[t]{2}{*}{ Conductivity $\left(\mu \mathrm{sm}^{-1}\right)$} & $70.2 \pm 5.49$ & $69.6 \pm 9.56$ & $70.2 \pm 8.98$ & $72.2 \pm 13.31$ \\
\hline & $(60.2-78.0)$ & $(57.1-104.4)$ & $(61.4-104.1)$ & $(61.2-119.1)$ \\
\hline \multirow[t]{2}{*}{$\mathrm{pH}$} & $7.1 \pm 0.43$ & $7.1 \pm 0.41$ & $7.0 \pm 0.40$ & $6.9 \pm 0.41$ \\
\hline & $(5.7-7.7)$ & $(5.9-7.7)$ & $(5.8-7.7)$ & $(5.8-7.5)$ \\
\hline \multirow[t]{2}{*}{ Dissolved Oxygen $\left(\mathrm{mg} \mathrm{L}^{-1}\right)$} & $8.2 \pm 1.08$ & $8.2 \pm 1.01$ & $8.3 \pm 1.10$ & $8.3 \pm 1.09$ \\
\hline & $(6.3-10.1)$ & $(5.7-9.7)$ & $(5.3-10.3)$ & $(5.8-10.5)$ \\
\hline \multirow[t]{2}{*}{ Nitrite $\left(\mu g \mathrm{~L}^{-1}\right)$} & $0.4 \pm 0.19$ & $0.4 \pm 0.18$ & $0.4 \pm 0.19$ & $0.4 \pm 0.17$ \\
\hline & $(0.2-0.7)$ & $(0.2-0.7)$ & $(0.1-0.7)$ & $(0.2-0.7)$ \\
\hline \multirow[t]{2}{*}{ Nitrate $\left(\mu \mathrm{g} \mathrm{L}^{-1}\right)$} & $8.2 \pm 5.56$ & $8.4 \pm 3.95$ & $6.2 \pm 2.89$ & $8.7 \pm 5.53$ \\
\hline & $(1.7-26.7)$ & $(3.3-15.7)$ & $(2.1-11.7)$ & $(1.3-21.7)$ \\
\hline \multirow[t]{2}{*}{ Ammonia $\left(\mu g \mathrm{~L}^{-1}\right)$} & $17.1 \pm 10.18$ & $15.2 \pm 7.68$ & $15.1 \pm 7.59$ & $14.0 \pm 6.52$ \\
\hline & $(6.0-50.2)$ & $(6.0-38.5)$ & $(5.1-36.1)$ & $(4.2-30.0)$ \\
\hline \multirow[t]{2}{*}{ Soluble Reactive Phosphorus ( $\left.\mu \mathrm{g} \mathrm{L}^{-1}\right)$} & $2.3 \pm 2.22$ & $2.3 \pm 2.25$ & $2.0 \pm 1.38$ & $2.5 \pm 1.81$ \\
\hline & $(0.2-10.2)$ & $(0.8-10.8)$ & $(0.6-6.2)$ & $(0.6-7.1)$ \\
\hline \multirow[t]{2}{*}{ Dissolved Organic Carbon (mg L-1) } & $3.2 \pm 0.42$ & $3.3 \pm 0.39$ & $3.2 \pm 0.33$ & $3.2 \pm 0.44$ \\
\hline & $(2.4-4.1)$ & $(2.7-4.3)$ & $(2.7-3.8)$ & $(2.5-4.5)$ \\
\hline \multirow[t]{2}{*}{ Total Nitrogen $\left(\mu \mathrm{g} \mathrm{L}^{-1}\right)$} & $513.4 \pm 271.10$ & $530.9 \pm 271.22$ & $516.5 \pm 281.95$ & $471.4 \pm 280.78$ \\
\hline & $(126.4-969.3)$ & $(90.6-927.6)$ & $(106.4-992.4)$ & $(106.4-965.1)$ \\
\hline \multirow[t]{2}{*}{ Total Phosphorus $\left(\mu \mathrm{g} \mathrm{L}^{-1}\right)$} & $11.7 \pm 3.10$ & $12.5 \pm 3.85$ & $12.9 \pm 5.28$ & $13.2 \pm 6.78$ \\
\hline & $(7.6-16.8)$ & $(6.8-19.7)$ & $(7.5-31.2)$ & $(8.2-39.1)$ \\
\hline \multirow[t]{2}{*}{ TN:TP } & $102.2 \pm 49.72$ & $103.9 \pm 53.78$ & $99.9 \pm 54.42$ & $90.6 \pm 52.72$ \\
\hline & $(17.5-198.0)$ & $(10.8-189.1)$ & $(12.8-211.2)$ & $(9.2-199.9)$ \\
\hline \multirow[t]{2}{*}{ Chlorophyll a $\left(\mu \mathrm{g} \mathrm{L}^{-1}\right)$} & $18.8 \pm 3.77$ & $19.4 \pm 3.33$ & $18.7 \pm 3.17$ & $18.6 \pm 3.13$ \\
\hline & $(10.7-24.2)$ & $(12.8-25.1)$ & $(13.1-25.2)$ & $(13.9-24.1)$ \\
\hline
\end{tabular}
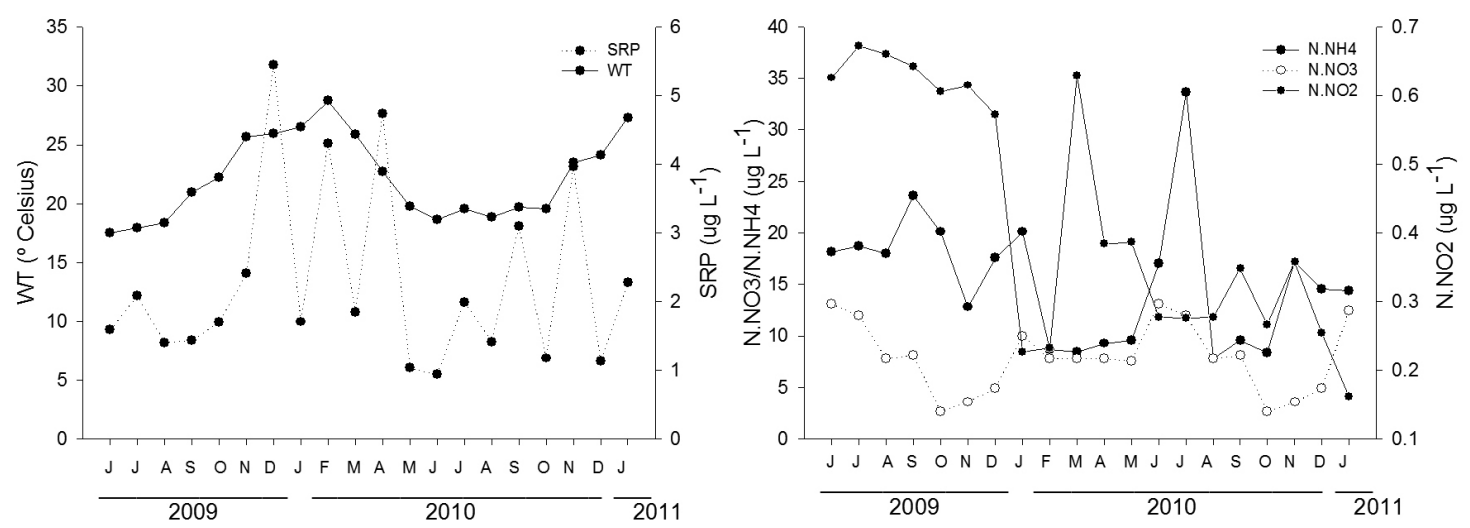

Figure 4. Monthly variations of water temperature (WT), soluble reactive phosphorus (SRP) and forms of dissolved inorganic nitrogen (N.NO2, N.NO3 and N.NH4) during sampling in the Peri Lake, from June/2009 to January/2011.

Chlorophyta showed higher richness than Cyanobacteria (Table 2), but low density, ranging from $1 \times 10^{3}$ ind. $\mathrm{mL}^{-1}$ in December/ 10 to $57 \times 10^{3}$ ind. $\mathrm{mL}^{-1}$ in January/10 (Figure 5). The high Chlorophyta density in January/10 was attributed to Monoraphidium irregulare that was the specie that more contributed to Chlorophyta density during the study period, and together with Actinastrum aciculare, presented the highest densities in this month.

Cylindrospermopsis raciborskii, Limnothrix sp., Planktolyngbya brevicellularis and Planktolyngbya limnetica were the most frequent Cyanobacteria species (>80\%) in Peri Lake during sampling 
Table 2. Phytoplanktonic species and frequency of occurrence (\%) observed in Peri Lake, from June/09 to January/11.

\begin{tabular}{|c|c|c|c|}
\hline Taxa & $\%$ & Taxa & $\%$ \\
\hline Cyanobacteria & & Chlorophyta & \\
\hline Aphanocapsa sp. & 43 & $\begin{array}{l}\text { Actinastrum aciculare Playfair var. aciculare } f \text {. } \\
\text { minimum (Huber-Pestalozzi) Compère }\end{array}$ & 59 \\
\hline Chroococcus turgidus (Kützing) Nägeli & 71 & Botryococcus sp. & 6 \\
\hline $\begin{array}{l}\text { Cylindrospermopsis raciborskii (Woloszynska) } \\
\text { Seenayya and Subba-Raju }\end{array}$ & 100 & Chlamydomonas sp. & 3 \\
\hline Limnothrix sp. & 89 & Chlorella homosphaera Skuja & 89 \\
\hline Microcystis cf. lameliformis Holsinger & 14 & Closterium sp. & 4 \\
\hline Planktolyngbya brevicellularis Cronberg e Komárek & 100 & Coelastrum polychordum (Korsikov) Hindák & 4 \\
\hline $\begin{array}{l}\text { Planktolyngbya limnetica (Lemmermann) Komárková- } \\
\text { Legnerová and Cronberg }\end{array}$ & 85 & $\begin{array}{l}\text { Cosmarium bioculatum Brébisson var. depressum } \\
\text { (Schaar.) Schmidle }\end{array}$ & 63 \\
\hline Pseudanabaena cf. galeata Böcher & 1 & Cosmarium sp.1 & 64 \\
\hline Dinophyta & & Cosmarium sp.2 & 34 \\
\hline Peridinium sp. & 68 & Monoraphidium arcuatum (Korsikov) Hindák & 73 \\
\hline Euglenophyta & & $\begin{array}{l}\text { Monoraphidium irregulare (Smith) Komárková- } \\
\text { Legnerová }\end{array}$ & 96 \\
\hline Euglena sp. & 41 & Scenedesmus cf. oahuensis (Lemmermann) Smith & 19 \\
\hline Trachelomonas sp. & 1 & Spyrogira sp. & 3 \\
\hline Bacillariophyta & & $\begin{array}{l}\text { Staurastrum pseudotetracerum (Nordstedt) West } \\
\text { and West }\end{array}$ & 40 \\
\hline Aulacoseira ambigua (Grunow) Simonsen & 39 & $\begin{array}{l}\text { Staurastrum tetracerum Ralfs var. evolutum West } \\
\text { and West }\end{array}$ & 48 \\
\hline Encyonema sp. & 33 & Staurodesmus cuspidatus (Bréb) Teiling & 4 \\
\hline Fragillaria sp. & 31 & Tetraedrum caudatum (Corda) Hansgirg & 70 \\
\hline
\end{tabular}
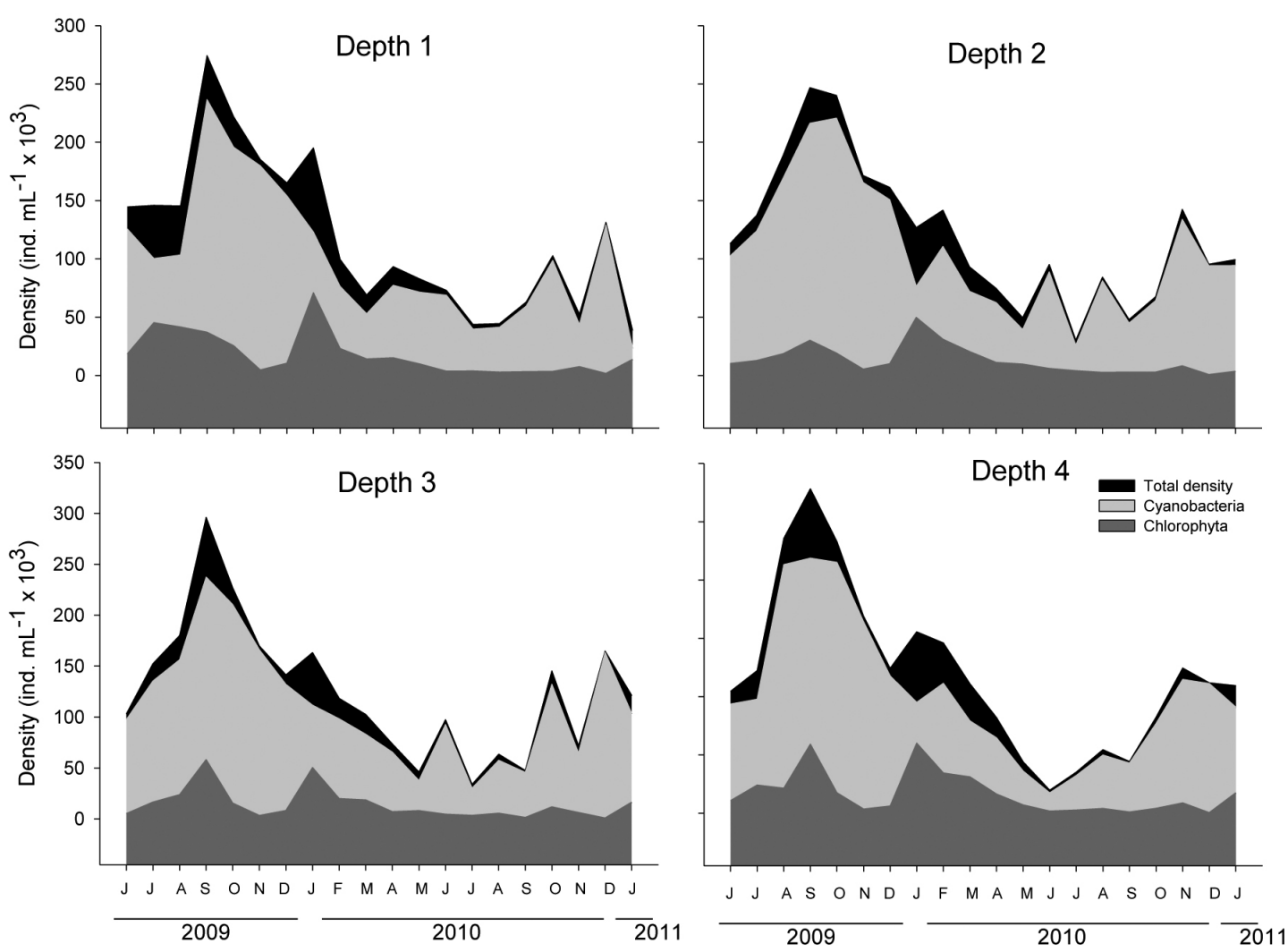

Figure 5. Total and groups phytoplankton density at four depths sampled in the Peri Lake, from June/2009 to January/2011. 
period. The Figure 6 shows the species and their density variation during 2009-2011. C. raciborskii was dominant along all period with the highest density, which resulted in low occurrence of other species. The density varied temporality from $23 \times 10^{3}$ ind. $\mathrm{mL}^{-1}$ in July/ 10 to $220 \times 10^{3}$ ind. $\mathrm{mL}^{-1}$ in September/09 (mean of four depths sampled in each month). For depth 1 the C. raciborskii average density was $82 \times 10^{3}$ ind. $\mathrm{mL}^{-1}$, for depth 2 it was $91 \times 10^{3}$ ind. $\mathrm{mL}^{-1}$, for depth 3 it was $93 \times 10^{3}$ ind. $\mathrm{mL}^{-1}$ and for depth 4 it was $82 \times 10^{3}$ ind. $\mathrm{mL}^{-1}$ (Kruskal-Wallis; $\mathrm{p}>0.05$ ). On average only $0.6 \%$ of $C$. raciborskii individuals were heterocyted, varying from $0.03 \%$ (June/09) to $3.11 \%$ (April/10).

Only in November/09 and December/09 Limnothrix sp. was dominant, while P. brevicellularis was constant along the study and P. limnetica exhibited the lowest density, except for August and September/10 (Figure 6). In March/10 the opportunist Chlorophyta M. irregulare was abundant together with C. raciborskii and Limnothrix sp.

The temporal variation of our data was explained $73.9 \%$ by the first axis and $18.4 \%$ by the second axis of the CCA (Figure 7). Variables loadings for the each axis can be found in Table 3, together with Monte Carlo test, that showed the water temperature $\left(\mathrm{R}^{2}=0.86, \mathrm{p}<0.001\right)$ and soluble reactive phosphorus $\left(\mathrm{R}^{2}=0.61, \mathrm{p}<0.001\right)$ as the most significant variables. Limnothrix sp. was correlated to increase in soluble reactive phosphorus, conductivity and water temperature recorded in November/09, December/09, March/10 and April/10. Increase in $A$. aciculare in January/10 was related to increase in dissolved organic carbon and $M$. irregulare was related to dissolved inorganic nitrogen and organic carbon. Both species increased its density in January/10 that contributed to high chlorophyll $a$ concentration in this month. On the other hand, P. limnetica was directly related to $\mathrm{pH}$ and other species did not differ, getting very close to the origin of the axes.

To explore the relationship between phytoplanktonic species and each form of nitrogen and other limnological variables, a Spearman correlation analysis was performed with species representative of this environment, specially the cyanobacterial species that were present during the whole study. We included in this analysis the presence of heterocyted trichomes of $C$. raciborskii and $M$. irregulare that presented periods of elevated density. Heterocyted trichomes of C. raciborskii were positively related to soluble reactive phosphorus and water temperature, while C. raciborskii was positively
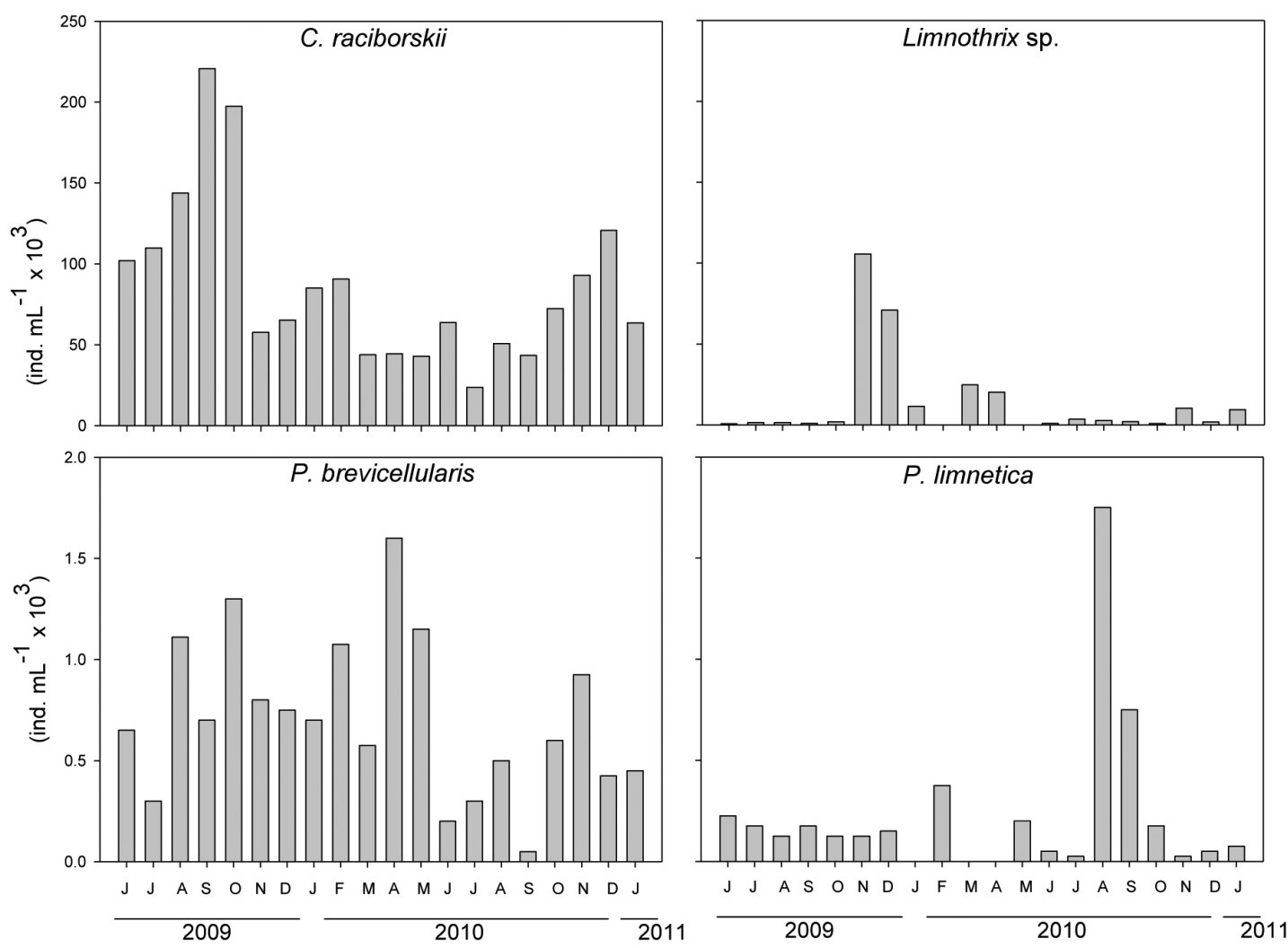

Figure 6. Cyanobacteria species density more frequent during sampling in Peri Lake, from June/2009 to January/2011. 
correlated only to ammonia (Table 4). Different species of Cyanobacteria showed correlation with variables in different ways. P. brevicellularis was negatively related with nitrate, while $P$. limnetica

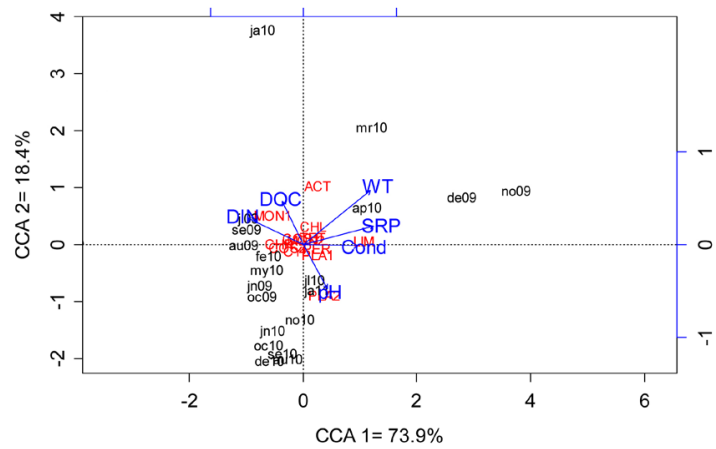

Figure 7. Canonical correspondence analysis (CCA) showing the ordination of the phytoplanktonic species in relation to the limnological variables. Abbreviations used: ACT: Actinastrum aciculare; CHL: Chlorella homosphaera; CHR: Chroococcus turgidus; COS1: Cosmarium sp.1; COS2: Cosmarium sp.2; CYL: Cylindrospermopsis raciborskii; LIM: Limnothrix sp.; MON1: Monoraphidium irregulare; MON2: $M$. arcuatum; PER: Peridinium sp.; PLA1: Planktolyngbya brevicellularis; PLA2: P. limnetica; TET: Tetraedrum caudatum; COND: conductivity; DIN: dissolved inorganic nitrogen; DOC: dissolved organic carbon; SRP: soluble reactive phosphorus; WT: water temperature. Letters mean the months of the year (ja: January; fe: February; mr: March; ap: April; ma: May; jn: June; jl: July; ag: August; sp: September; oc: October; no: November; de: December), while numbers mean the year (09: 2009; 10: 2010; 11: 2011).

Table 3. Values of the environmental variables with the axes 1 and 2 of CCA and Monte Carlo test.

\begin{tabular}{crrcc}
\hline Variables & CCA1 & CCA2 & $\begin{array}{c}\text { Monte Carlo } \\
\text { test }\left(\mathbf{R}^{2}\right)\end{array}$ & $\begin{array}{c}\text { Monte Carlo } \\
\text { test }(\mathbf{p})\end{array}$ \\
\hline DIN & -0.90 & 0.43 & 0.44 & 0.010 \\
SRP & 0.97 & 0.25 & 0.61 & 0.001 \\
WT & 0.78 & 0.63 & 0.86 & 0.001 \\
Cond & 0.99 & -0.03 & 0.34 & 0.021 \\
pH & 0.48 & -0.88 & 0.29 & 0.076 \\
DOC & -0.44 & 0.90 & 0.26 & 0.096 \\
\hline
\end{tabular}

had a negative correlation with Zeu:Zmix. On other hand, Limnothrix sp. had correlation with soluble reactive phosphorus, conductivity and water temperature, similar to heterocyted trichomes. $M$. irregulare had positive correlation with nitrite and dissolved organic carbon.

\section{Discussion}

Wind is the principal variable which promotes water column mixing in coastal lakes (Cardoso and Motta Marques, 2004; Crosseti et al., 2007). Since, in this study limnological variables at four sampled depths did not demonstrate significant vertical variation we suggest that wind velocity was enough to promote the water column mixing.

In well-mixed lakes the euphotic zone is lower than the mixed zone, thus organisms spend relatively more time in darkness, and this feature selected the Sn and S1 functional groups in Peri Lake (Reynolds et al., 2002; Padisák et al., 2009). The former is characterized of warm mixed environment, nitrogen deficient conditions and flushing habitat, which $C$. raciborskii is part of, and the second includes Limnothrix sp., P. limnetica and P. brevicellularis, characterized as a turbid mixed environment and highly light-deficient conditions. Among them, P. limnetica seems to have the most light uptake capacity since it was the only species that showed a negative correlation with Zeu:Zmix. This light limitation tolerance is common to some Cyanobacteria species, for example, in Carioca Lake the population of P. limnetica (cited as Lyngbya limnetica) was centered at a depth of $6.5 \mathrm{~m}$ (metalimnion), where light penetration is less than $1 \%$ of the red and green wavelengths (Reynolds et al., 1983).

Among Cyanobacteria species recorded in Peri Lake, $C$. raciborskii and $P$. brevicellularis were more constant during the seasonal cycle. The former presented positive correlation with ammonia, as recorded by Berman et al. (1984) and Burford et al. (2007), in which this species demonstrated preferential uptake of ammonia over nitrate. The

Table 4. Spearman correlation coefficient performed between phytoplanktonic species and limnological variables.

\begin{tabular}{lcccccccrr}
\hline & Zeu:Zmix & N.NO2 & N.NO3 & N.NH4 & SRP & WT & Cond & pH & DOC \\
\hline Heterocyted trichomes & 0.09 & -0.29 & -0.28 & 0.15 & $0.50^{*}$ & $0.58^{*}$ & 0.21 & 0.36 & 0.14 \\
P.brevicellularis & -0.26 & 0.24 & $-0.52^{*}$ & -0.02 & 0.19 & 0.28 & 0.00 & 0.04 & 0.42 \\
P.limnetica & $-0.50^{*}$ & 0.13 & -0.05 & -0.24 & -0.11 & -0.35 & -0.15 & -0.30 & -0.08 \\
C. raciborskii & -0.37 & 0.28 & -0.15 & $0.47^{*}$ & -0.19 & -0.09 & -0.39 & -0.12 & 0.31 \\
Limnothrix sp. & 0.27 & 0.01 & -0.16 & 0.00 & $0.57^{*}$ & $0.47^{*}$ & $0.62^{*}$ & 0.08 & -0.04 \\
M. irregulare & -0.17 & $0.53^{*}$ & 0.04 & 0.39 & 0.06 & 0.03 & -0.29 & -0.42 & $0.72^{*}$ \\
\hline
\end{tabular}

*represents significant $(\mathrm{p}<0.05, \mathrm{n}=80)$. 
correlations observed in Table 4 suggest co-existence or competition between some species.

Limnothix sp. densities exceeded those of C. raciborskii in November and December/09 and this high density can be interpreted as dominance over C. raciborskii. However, this was due to disintegration of trichomes, which in November/09 was influenced by decrease in dissolved inorganic nitrogen, which resulted in increase to around $0.9 \%$ the $C$. raciborskii filaments carrying heterocytes. In December/09, recovery was observed in the dissolved inorganic nitrogen levels, and decreases the heterocyted trichomes of $C$. raciborskii $(0.8 \%)$, soluble reactive phosphorus peaked, and temperature increased, consequently Limnothrix sp. population presented recovery of trichomes and a real growth, suggesting that Limnothrix sp. seems to be better competitor than $C$. raciborskii for soluble reactive phosphorus. In addition, in November/09 was recorded low wind speed that can favor Limnothrix sp. to remain more time in water column. However, wind values were recorded during sample collection and should be considered more carefully, since this may not represent the real environmental condition.

Branco and Senna (1994) have observed that high concentration of ammonia recorded in Paranoá Reservoir inhibited the development of heterocytes in $C$. raciborskii, corroborated by the fact that heterocytes were observed only in the months when a low level of ammonia was registered. In Peri Lake, heterocytes were not inhibited by ammonia, occurring with varying densities throughout the period analyzed. It is believed that low concentrations of ammonia present in Peri Lake, would be insufficient to inhibit heterocytes production. C. raciborskii from Balaton Lake continued to fix nitrogen under presence of $10 \mu \mathrm{g} \mathrm{L}^{-1}$ of ammonia (Spröber et al., 2003). Nutrient experiments bioassay conducted by Moisander et al. (2008) have shown low but detectable nifH gene expression, related with nitrogenase activity, in the field when ammonia was present and is consistent with the observation from culture experiments.

C. raciborskii filaments carrying heterocytes were positively correlated with phosphorus and temperature, showing that its availability stimulates the diazotrophic metabolism of this species. In diazotrophic species the light requirements are often lower when grown on a combined nitrogen source than when grown on $\mathrm{N}_{2}$ (Agawin et al., 2007). However, in Peri Lake, C. raciborskii seems to be a better competitor under a broad range of nitrogen conditions, ranging from diazotrophic to a non-diazotrophic metabolism, which is another reason for its dispersion world-wide, pointed out by Moisander et al. (2012). The low proportion of $C$. raciborskii filaments carrying heterocytes recorded in this study is similar to found in other Brazilian environments according to Bouvy et al. (2000).

$M$. irregulare showed high positive correlation with dissolved organic carbon, this suggests that it is a mixotrophic species and can simultaneously use the photosynthetic function and organic carbon uptake similar to other Chlorococcales (Cohen and Post, 1993). M. irregulare could not belong to the functional group X1 characterized from eutrophic-hypereutrophic environments, sensitive to nutrients deficiency and stratification tolerant in which multiple species of this genera have been included (Padisák et al., 2009). Despite having small size and high surface:volume ratio, like c-strategist, tolerates nutrients deficiency and continuous turbulent transport through a light gradient like $S$ and R strategist.

The phytoplankton community showed varying behavior along the sampled period. The first half of period was very different from the second half, showing the highest growth peak in early spring. In the second half of the period, the highest peak growth occurred in late spring, with the maximum density reaching about half of the previous period. The first spring peak occurred after an enhanced winter growth. In the second half of the period, the autumn/winter growth was very low, where the lowest density around the period studied occurred (July/10). In the first half, the largest contribution was given by the Cyanobacteria and Chlorophyta. Cyanobacteria peaked in September/09 and Chlorophyta peaked in September/09 and January/10 reflecting high $M$. irregulare growth. In the second half, Cyanobacteria were the main contributors to the phytoplankton density and Chlorophyta showed less variation. The other phytoplankton groups had less expression.

The dynamic relationship between phytoplankton and nutrients has been of great interest. The data reveal that Peri Lake is a nutrientpoor lake, with absolute low concentrations for $\mathrm{N}$ - and P-combined and dissolved nutrients considered limiting for phytoplankton growth (Reynolds, 1999). However, in this environment, Cyanobacteria were the dominant group, composed of species that are good competitors. 
In general, the total density of phytoplankton have been increased considerably since LaudaresSilva (1999), where the variations were from $3 \times 10^{3}$ ind. $\mathrm{mL}^{-1}$ to $41 \times 10^{3}$ ind. $\mathrm{mL}^{-1}$ between 1996 and 1997, and recorded by Grellmann (2006) along 2004-2005, with variations from $40 \times 10^{3}$ ind. $\mathrm{mL}^{-1}$ to $116 \times 10^{3}$ ind. $\mathrm{mL}^{-1}$. While Laudares-Silva (1999) registered 16 abundant taxa, this study recorded only three taxa (C. raciborskii, Limnothrix sp. and M. irregulare). The physiological flexibility and phenotypic plasticity of the $C$. raciborskii ensures its competitive edge and could explain its ongoing expansion to other latitudes (Bonilla et al., 2012) decreasing the occurrence of other species as also described by Bouvy et al. (2000).

Permanent cyanobacterial dominance is, therefore, regarded as the ultimate phase of eutrophication occurring world-wide (Dokulil and Teubner, 2000). However, the reasons for such outbreaks largely remain unclear, especially in Peri Lake, a nutrients limited environment, in which $C$. raciborskii have been recorded since the mid-1990s, with constant density increase. The dominance of filamentous Cyanobacteria in a German lake have been attributed to lightdeficient conditions caused by high shading effects, induced by high biomass, therefore suppressing other phytoplankton associations (Mischke and Nixdorf, 2003).

The main environmental variables responsible for the greatest variation in phytoplankton community, identified using CCA, were nitrogen, phosphorus and temperature. Recent studies have demonstrated that high temperature and increase in nutrients concentration result in decreasing of Chlorophyta and increasing of Cyanobacteria. There are also the abiotic variables with a greater influence over both spatial and temporal distribution of the phytoplankton community (Dantas et al., 2008; Becker et al., 2010). Nevertheless, only heterocyted trichomes of $C$. raciborskii and Limnothrix sp. densities were positively correlated to water temperature that may have an indirect effect by controlling the availability of resources. Thus, the data demonstrate that discrete alterations in phytoplankton community present predicable periodicity driven by annual change in these variables, always favoring Cyanobacteria.

In summary, Peri Lake's features allows the occurrence of a vertically homogeneous water column, due turbulence, and the dominance of cyanobacterial functional groups adapted to low underwater light and nutrients deficiency. The phytoplankton presented periodicity driven by annual change in water temperature and nutrients availability. The partitioning or competition by resource between cyanobacterial species is suggested.

\section{Acknowledgements}

We would like to thank Danilo Funke (FLORAM/ Peri Lake Municipal Park) and Alex Pires De Oliveira Nuñer (LAPAD - UFSC) for help of field and lab equipments and the Programa de Pós-Graduação em Ecologia - UFSC. This study was funded by CNPq - Brazil (Conselho Nacional de Desenvolvimento Científico e Tecnológico; Universal Process: 473572/2008-7) and the first author was supported by CAPES (Coordenação de Aperfeiçoamento de Pessoal de Nível Superior).

\section{References}

AGAWIN, NSR., RABOUILLE, S., VELDHUIS, MJW., SERVTIUS, L., HOL, S., VAN OVERZEE, HMJ. and HUISMAN, J. 2007. Competition and facilitation between unicellular nitrogenfixing cyanobacteria and non-nitrogen-fixing phytoplankton species. Limnology and Oceanography, vol. 52, no. 5, p. 2233-2248. http://dx.doi. org/10.4319/lo.2007.52.5.2233

BECKER, V., CAPUTO, L., ORDÓÑEZ, J., MARCÉ, R., ARMENGOL, J., CROSSETI, L. and HUSZAR, V. 2010. Driving factors of the phytoplankton functional groups in a deep Mediterranean reservoir. Water Research, vol. 44, no. 11, p. 3345-3354. PMid:20398914. http://dx.doi.org/10.1016/j. watres.2010.03.018

BERMAN, T., SHERR, BF., SHERR, E., WYNNE, D. and McCARTHY, JJ. 1984. The characteristics of ammonium and nitrate uptake by phytoplankton in Lake Kinneret. Limnology and Oceanography, vol. 29, no. 2, p. 287-297. http://dx.doi.org/10.4319/ lo.1984.29.2.0287

BONILLA, S., AUBRIOT, L., SOARES, MCS., GONZÁLES-PIANA, M., FABRE, A., HUSZAR, VLM., LURLING, M., ANTONIADES, D., PADISÁK, J. and KRUK, C. 2012. What drives the distribution of the bloom-forming cyanobacteria Planktothrix agardhii and Cylindrospermopsis raciborskii? FEMS Microbiol Ecological, vol. 79, no. 3, p. 594-607. PMid:22092489. http://dx.doi. org/10.1111/j.1574-6941.2011.01242.x

BOUVY, M., FACÃO, D., MARINHO, M., PAGANO, M. and MOURA, A. 2000. Occurrence of Cylindrospermopsis (Cyanobacteria) in 39 Brazilian tropical reservoirs during the 1998 drought. Aquatic Microbial Ecology, vol. 23, no. 1, p. 13-27. http:// dx.doi.org/10.3354/ame023013 
BRANCO, CWC. and SENNA, PAC. 1994. Factors influencing the development of Cylindrospermopsis raciborskii and Microcystis aeruginosa in Paranoá Reservoir, Brasília, Brazil. Algological Studies, vol. 75, p. 85-96.

BURFORD, MA., JOHNSON, SA., COOK, AJ., PACKER, TV., TAYLOR, BM. and TOWNSLEY, ER. 2007. Correlations between watershed and reservoir characteristics, and algal blooms in subtropical reservoirs. Water Research, vol. 41, no. 18, p. 4105-4114. PMid:17632205. http://dx.doi. org/10.1016/j.watres.2007.05.053

CARDOSO, L. and MOTTA MARQUES, D. 2004. Seasonal composition of the phytoplankton community in Itapeva Lake (north coast of Rio Grande do Sul - Brazil) in function of hydrodynamic aspects. Acta Limnologica Brasiliensia, vol. 16, no. 4, p. 401-416.

COLE, GA. 1994. Textbook of Limnology. Publisher: Waveland. $412 \mathrm{p}$.

COHEN, I. and POST, AF. 1993. The heterotrophic connection in a photoautotrophic Chlorella vulgaris dominant in wasterwater oxidation ponds. Water Science and Technology, vol. 27, no. 7-8, p. 151-155.

CROSSETI, LO., CARDOSO, LS., CALLEGARO, VLM., ALVES-DA-SILVA, SM., WERNER, VR., ROSA, ZM. and MOTTA MARQUES, D. 2007. Influence of the hydrological changes on the structure and dynamics in a subtropical wetland-lake system. Acta Limnologica Brasiliensia, vol. 19, no. 3, p. 315329.

CROSSETI, LO. and BICUDO, CEM. 2008. Adaptations in phytoplankton life strategies to imposed change in a shallow urban tropical eutrophic reservoir, Garças Reservoir, over 8 years. Hydrobiologia, vol. 614, p. 91-105. http://dx.doi. org/10.1007/s10750-008-9539-1

DANTAS, ÊW., MOURA, AN., BITTENCOURTOLIVEIRA, MC., ARRUDA NETO, JDT. and CAVALCANTI, AD. 2008. Temporal variation of the phytoplankton community at short sampling intervals in the Mundaú reservoir, Northeastern Brazil. Acta Botanica Brasilica, vol. 22, no. 4, p. 970-982. http://dx.doi.org/10.1590/S010233062008000400008

DANTAS, ÊW., BITTENCOURT-OLIVEIRA, MC. and MOURA, AN. 2012. Dynamics of phytoplankton associations in three reservoirs in northeastern Brazil assessed using Reynolds' theory. Limnologica, vol. 42, p. 72- 80. http://dx.doi. org/10.1016/j.limno.2011.09.002

DOKULIL, MT. andTEUBNER, K. 2000. Cyanobacterial dominance in lakes. Hydrobiologia, vol. 438, p. 1-12. http://dx.doi.org/10.1023/A:1004155810302

DOWNING, JA., WATSON, SB. and McCAULEY, E. 2001. Predicting Cyanobacteria dominance in lakes. Canadian Journal Fish Aquatic Science, vol. 58, p. 1905-1908. http://dx.doi.org/10.1139/f01-143

GOLTERMAN, HL., CLYMO, RS. and OHNSTAD, MAM. 1978. Methods for physical and chemical analysis of freshwater. Oxford: Blackwell Sci. Plublisher. 213 p.

GRELLMANN, C. 2006. Aspectos da Morfologia $e$ da Ecologia de Cylindrospermopsis raciborskii (Woloszynska) Seenayya Et Subba Raju e da Produção de Cianotoxinas na Lagoa do Peri, Florianópolis, SC, Brasil. Florianópolis: Universidade Federal de Santa Catarina. 76 p. [Dissertação de Mestrado].

HASLE, G. 1978. The invert-microscope method. In SOURNIA, A., org. Phytoplankton Manual. Paris: Monographs on Oceanographic Methodology, Unesco Publishers. p. 88-96.

HENNEMANN, MC. and PETRUCIO, MM. 2010. Seasonal phytoplankton response to increased temperature and phosphorus inputs in a freshwater coastal lagoon, Southern Brazil: a microcosm bioassay. Acta Limnologica Brasiliensia, vol. 22, no. 3, p. 295 305. http://dx.doi.org/10.4322/actalb.02203006

HENNEMANN, MC. and PETRUCIO, MM. 2011. Spatial and temporal dynamic of trophic relevant parameters in a subtropical coastal lagoon in Brazil. Environmental Monitoring and Assessment, vol. 181, p. 347-361. PMid:21190080. http://dx.doi. org/10.1007/s10661-010-1833-5

HUSZAR, VLM., SILVA, LHS., MARINHO, M., DOMINGOS, P. and SANT'ANNA, CL. 2000. Cyanoprokaryote assemblages in eight productive tropical Brazilian Waters. Hydrobiologia, vol. 424, p. 6777. http://dx.doi.org/10.1023/A:1003996710416

KOMÁRKOVÁ, J., LAUDARES-SILVA, R. and SENNA, PAC. 1999. Extreme morphology of Cylindrospermopsis raciborskii (Nostocales, Cyanobacteria) in the Lagoa do Peri, a freshwater coastal lagoon, Santa Catarina, Brazil. Algological Studies, vol. 94, p. 207-222.

KOROLEFF, F. 1976. Determination of nutrients. In GRASSHOFF, K., org. Methods of sea water analysis. Verlagein Chemie Weinhein. p. 117-181.

KOSTEN, S., HUSZAR, VLM., BÉCARES, E., COSTA, LS., van DONK, E., HANSSON, LA., JEPPESEN, E., KRUK, C., LACEROT, G., MAZZEO, N., MEESTER, L., MOSS, B., LURLING, M., NÓGES, T., ROMO, S. and SCHEFFER, M. 2012. Warmer climates boost cyanobacterial dominance in shallow lakes. Global Change Biology, vol. 18, p. 118-126. http://dx.doi. org/10.1111/j.1365-2486.2011.02488.x

LAUDARES-SILVA, R. 1999. Aspectos limnológicos, variabilidade especial e temporal na estrutura da comunidade fitoplanctônica da Lagoa do Peri, Santa Catarina, Brasil. 216 p. [Tese de Doutorado]. São Carlos: Universidade Federal de São Carlos. 
LOBO, EA. and LEIGHTON, G. 1986. Estruturas comunitarias de las fitocenoses planctônicas de los sistemas de desembocaduras de rios e esteros de La zona central do Chile. Revista de Biologia Marinha, vol. 22, no. 1, p. 1-9.

LORENZEN, CJ. 1967. Determination of chlorophyll and pheopigments: Spectrophotometric equations. Limnology and Oceanography, vol. 12, no. 2, p. 343346. http://dx.doi.org/10.4319/lo.1967.12.2.0343

MACKERETH, FJH., HERON, JE. and TALLING, JF. 1978. Water Analysis: some revised methods for limnologists. Freshwater Biological Association. Scientific Publication, no. 36, 120 p.

MISCHKE, U. and NIXDORF, B. 2003. Equilibrium phase conditions in shallow German lakes: How Cyanoprokaryota species establish a steady state phase in late summer Hydrobiologia, vol. 502, p. 123-132. http://dx.doi.org/10.1023/ B:HYDR.0000004275.81490.92

MOISANDER, PH., PAERL, HW. and ZEHR, JP. 2008. Effects of inorganic nitrogen on taxaspecific cyanobacterial growth and nifH expression in a subtropical estuary. Limnology and Oceanography, vol. 53, no. 6, p. 2519-2532. http://dx.doi. org/10.4319/lo.2008.53.6.2519

MOISANDER, PH., CHESHIRE, LA., BRADDY, J., CALANDRINO, ES., HOFFMAN, M., PIEHLER, MF. and PAERL, HW. 2012. Facultative diazotrophy increases Cylindrospermopsis raciborskii competitiveness under fluctuating nitrogen availability. FEMS Microbiol Ecology, vol. 79, p. 800811. PMid:22126519. http://dx.doi.org/10.1111/ j.1574-6941.2011.01264.x

OKSANEN, J., KINDT, R., LEGENDRE, P., O'HARA, B., SIMPSON, GL., STEVENS, MHH. and WAGNER, H. 2008. Vegan: Community Ecology Package. R package version 1.13-1. Available from: $<$ http://vegan.r-forge.r-project.org/>.

PADISÁK, J. 1997. Cylindrospermopsis raciborskii (Woloszynska) Seenayya et Subba Raju, an expanding highly adaptive blue-green algal species: worldwide distribution and review of its ecology. Archiv für Hydrobiologie, vol. 107, p. 563-593.

PADISÁK, J., CROSSETTI, LO. and NASELLIFLORES, L. 2009. Use and misuse in the application of the phytoplankton functional classification: a critical review with updates. Hydrobiologia, vol. 621, p. 1-19. http://dx.doi.org/10.1007/s10750-008$9645-0$
R Development Core Team. 2008. R: A language and environment for statistical computing. Vienna: $\mathrm{R}$ Foundation for Statistical Computing. Available from: <http://www.R-project.org>.

REJMÁNKOVÁ, E., KOMÁREK, J., DIX, M., KOMÁRKOVÁ, J. and GIRÓN, N. 2011. Cyanobacterial blooms in lake Atitlan, Guatemala. Limnologica, vol. 41, p. 296-302. http://dx.doi. org/10.1016/j.limno.2010.12.003

REYNOLDS, CS., TUNDISI, JG. and HINO, K. 1983. Observations on a metalimnetic Lyngbya population in a stably stratified tropical lake (Lagoa Carioca, Eastern Brazil). Archive fur Hydrobiologie, vol. 97, p. 7-17.

REYNOLDS, CS. 1999. Non-determinism to probability, or N:P in the community ecology of phytoplankton. Archive fur Hydrobiologie, vol. 146, no. 1, p. 23-35.

REYNOLDS, CS., HUSZAR, V., KRUK, C., NASELLI-FLORES, L. and MELO, S. 2002. Towards a functional classification of the freshwater phytoplankton. Journal of Plankton Research, vol. 24, no. 5, p. 417-428. http://dx.doi.org/10.1093/ plankt/24.5.417

SALMASO, N. 2011. Interactions between nutrient availability and climatic fluctuations as determinants of the long-term phytoplankton community changes in Lake Garda, Northern Italy. Hydrobiologia, vol. 660, p. 59-68. http://dx.doi.org/10.1007/ s10750-010-0394-5

SPRÖBER, P., SHAFIK, HM., PRÉSING, M., KOVÁCS, AW. and HERODEK, S. 2003. Nitrogen uptake and fixation in the cyanobacterium Cylindrospermopsis raciborskii under different nitrogen conditions. Hydrobiologia, vol. 509, p. 169-174. http://dx.doi. org/10.1023/B:HYDR.0000008617.90245.5f

STRICKLAND, JDH. and PARSONS, TR. 1960. A manual of seawater analysis. Bulletin Fish Research Board Canadian, no. 125, 185 p.

VALDERRAMA, JC. 1981. The simultaneous analysis of total nitrogen and phosphorus in natural waters. Marine Chemistry, vol. 10, no. 2, p. 109-122. http:// dx.doi.org/10.1016/0304-4203(81)90027-X

ZHU, W., WAN, L. and ZHAO, L. 2010. Effect of nutrient level on phytoplankton community structure in different water bodies. Journal of Environmental Sciences, vol. 22, no. 1, p. 32-39. http://dx.doi.org/10.1016/S1001-0742(09)60071-1 